\title{
Differentiating a Republican Citizenry: Talents, Human Science, and Enlightenment Theories of Governance
}

\author{
John Carson \\ Osiris, 2nd Series, Vol. 17, Science and Civil Society. (2002), pp. 74-103.
}

Stable URL:

http://links.jstor.org/sici?sici=0369-7827\%282002\%292\%3A17\%3C74\%3ADARCTH\%3E2.0.CO\%3B2-Z

Osiris is currently published by The University of Chicago Press.

Your use of the JSTOR archive indicates your acceptance of JSTOR's Terms and Conditions of Use, available at http://www.jstor.org/about/terms.html. JSTOR's Terms and Conditions of Use provides, in part, that unless you have obtained prior permission, you may not download an entire issue of a journal or multiple copies of articles, and you may use content in the JSTOR archive only for your personal, non-commercial use.

Please contact the publisher regarding any further use of this work. Publisher contact information may be obtained at http://www.jstor.org/journals/ucpress.html.

Each copy of any part of a JSTOR transmission must contain the same copyright notice that appears on the screen or printed page of such transmission.

The JSTOR Archive is a trusted digital repository providing for long-term preservation and access to leading academic journals and scholarly literature from around the world. The Archive is supported by libraries, scholarly societies, publishers, and foundations. It is an initiative of JSTOR, a not-for-profit organization with a mission to help the scholarly community take advantage of advances in technology. For more information regarding JSTOR, please contact support@jstor.org. 


\title{
Differentiating a Republican Citizenry: Talents, Human Science, and Enlightenment Theories of Governance
}

\author{
By John Carson*
}

\begin{abstract}
This essay explores how the Enlightenment preoccupation with nature and reason, and the concomitant desire to restructure civil and political society according to these principles, served simultaneously to write certain speculations within mental philosophy into the heart of the republican project and to orient the emerging human sciences toward embracing those social formations most consonant with the developing notions of the republican citizen and the enlightened society. Using the development of the language of talents in the eighteenth century as its focus, the essay examines how Enlightenment political writers and mental philosophers-including Locke, Hartley, Condillac, Cabanis, Rousseau, Helvétius, Godwin, Paine, Wollstonecraft, Jefferson, and Adams-elaborated a vision, on the one hand, of a new social-political order founded on merit and, on the other, of human nature as an object of both scientific and political interest.
\end{abstract}

\section{INTRODUCTION}

For I agree with you that there is a natural aristocracy among men. The grounds of this are virtue and talents.... There is also an artificial aristocracy founded on wealth and birth, without either virtue or talents; for with these it would belong to the first class. The natural aristocracy I consider as the most precious gift of nature for the instruction, the trusts, and government of society. . . . May we not even say that that form of government is the best which provides the most effectually for a pure selection of these natural aristoi into the offices of government? The artificial aristocracy is a mischievous ingredient in government, and provision should be made to prevent its ascendancy. ${ }^{1}$

So Thomas Jefferson wrote his old friend and political rival John Adams on 28 October 1813 in response to two letters from Adams discussing the kind of political leadership the new nation needed and could expect. Ever the more cynical of the two in his view of human nature, Adams had remarked in one of those letters that

\footnotetext{
* Department of History, University of Michigan, 1029 Tisch Hall, Ann Arbor, MI 48109-1003; jscarson@umich.edu.

I particularly wish to thank David Bien, Tom Broman, Michelle Craig, Eric Daniels, Dena Goodman, Ray Grew, Lynn Nyhart, Kathy Olesko, Dan Rodgers, Andrea Rusnock, the anonymous reviewers of the article for Osiris, the participants in the "Science and Civil Society: Historical Perspectives" workshop, the students in my "Human Natures and Social Orderings" graduate seminar at the University of Michigan, and the members of the European History Colloquium at Cornell University for their suggestions, encouragement, and careful readings of earlier drafts of this article.

${ }^{1}$ Thomas Jefferson to John Adams, 28 Oct. 1813, Adams-Jefferson Letters, ed. Lester J. Cappon (Chapel Hill: Univ. of North Carolina Press, 1988), p. 388.
} 
"Birth and Wealth together have prevailed over Virtue and Talents in all ages." ${ }^{2}$ Later he responded to the lofty sentiments in Jefferson's October letter by providing his own rather less refined definition of an aristocrat: anyone able to command or influence votes other than his own, whether obtained "by his Birth, Fortune, Figure, Eloquence, Science, learning, Craft Cunning, or even his Character for good fellowship and a bon vivant." ${ }^{3}$ Having brought Jefferson's vision of the aristoi back down to earth, Adams then made clear his own distaste for an aristocracy of any sort:

And both artificial Aristocracy, and Monarchy, and civil, military, political and hierarchical Despotism, have all grown out of the natural Aristocracy of 'Virtues and Talents.' We, to be sure, are far remote from this. Many hundred years must roll away before We shall be corrupted. Our pure, virtuous, public spirited federative Republick will last for ever, govern the Globe and introduce the perfection of Man, his perfectability being already proved by Price Priestly, Condorcet Rousseau Diderot and Godwin. ${ }^{4}$

Adams's sarcasm notwithstanding, Jefferson's conception of rule by the natural aristocracy clearly struck a nerve, reminding Adams vividly of the doctrines of all those other high priests of Enlightenment political speculation he had spent a career debating. By 1813 such concerns would have already seemed more than a little fusty in a country moving headlong toward dramatic expansions of the suffrage and toward dismantling some of the intricate codes of deference that had marked eighteenth-century social life. But clearly both ex-presidents were looking as much backward as forward and continuing debates that had been pressed since the middle of the eighteenth century in France and Britain as well as America about the nature of society and governance in a republic. ${ }^{5}$

Three aspects of their exchange highlight important features of this transatlantic Enlightenment conversation. First, it is striking that the author of the Declaration of Independence, with its grand commitment to the equality of all human beings, could so blithely assert that some individuals were by nature superior to others and thus better suited to rule. Jefferson was not simply being contradictory, nor had he merely become more conservative with age. Rather, like many of his peers in the Atlantic community who had been puzzling over the nature of a republican society, Jefferson distinguished between certain basic political rights, which he believed applied broadly to whole categories of citizens, and allocations of civic and political power, which he argued should accrue to individuals as a result of their particular sets of virtues and talents. ${ }^{6}$ In this Jefferson was by no means alone. The language

${ }^{2}$ Adams to Jefferson, 9 July 1813, Adams-Jefferson Letters (cit. n. 1), p. 352.

${ }^{3}$ Adams to Jefferson, 15 Nov. 1813, Adams-Jefferson Letters (cit. n. 1), p. 398.

${ }^{4}$ Ibid., p. 400.

${ }^{5}$ On the issue of the "natural aristocracy" and its place in late-eighteenth-century politics, see J. G. A. Pocock, The Machiavellian Moment: Florentine Political Thought and the Atlantic Republican Tradition (Princeton, N.J.: Princeton Univ. Press, 1975), pp. 513-26; and Gordon S. Wood, The Creation of the American Republic, 1776-1787 (New York: W. W. Norton, 1969), especially chap. 12.

${ }^{6} \mathrm{I}$ have spoken here of rights being ascribed to categories of people to attempt to capture some of the complexity of a political world in which only white, propertied, adult males were accorded full citizenship rights, while women, children, indentured servants, slaves, native peoples, recent immigrants, to name only a few categories, had various limitations placed on the kinds of rights they could claim. In a letter to Henri Grégoire on 25 Feb. 1809, Jefferson himself hinted at this distinction between rights and the rewards of talent, discussing his assessment of African Americans. "Be assured that no person living wishes more sincerely than I do, to see a complete refutation of the doubts I have myself entertained and expressed on the grade of understanding allotted to them [blacks] by nature, and to find that in this respect they are on a par with ourselves.... [B]ut whatever be their 
of universal rights, historian Daniel T. Rodgers has pointed out, took on enormous power and importance in America during the second half of the eighteenth century and was equally warmly embraced throughout many parts of the Atlantic world. ${ }^{7}$ At the same time, from plans to reform the French army to projects to educate the masses, numerous attempts were made to wed commitment to a universalistic right, such as equality of opportunity, with systems that would award positions of power and authority on the basis of individual ability. Thus lower-level nobles argued that officerships in the French army should be determined by competence, not social rank, and natural philosophers that positions such as those at the Académie des Sciences or prizes awarded by such groups should be open to all and determined solely on the basis of talent, regardless of social origins. ${ }^{8}$

Second, both Jefferson and Adams acknowledged, albeit from very different perspectives, that stratifications in civil and political society would inevitably persist, even within the most privileged class of white, propertied males. "Was there, or will there ever be," Adams wondered in 1787, "a nation, whose individuals were all equal, in natural and acquired qualities, in virtues, talents, and riches? The answer of all mankind must be in the negative." 9 While certainly more optimistic than Adams about the potential of education and abundant land to produce rough equality (at least for adult, white males) within a politically engaged republic of yeoman farmers, Jefferson conceded that society would remain divided; he hoped, however, to ensure that such divisions were based on the right criteria, the reward for an individual's virtues and talents rather than the legacy of family or rank. ${ }^{10}$ Few indeed among the educated classes of the eighteenth century, whether in America or Europe, imagined the possibility of either a civic society or a political culture in which stratification and difference were not an integral part of the social order. Even Alexis de Tocqueville's much later ruminations on the nature of an egalitarian society, Democracy in America $(1835,1840)$, sketch a nation in which the logic of democracy

degree of talent is no measure of their rights. Because Sir Isaac Newton was superior to others in understanding, he was not therefore lord of the person or property of others." The Portable Thomas Jefferson, ed. Merrill D. Peterson (New York: Penguin Books, 1977), p. 517. For an earlier moment in the history of virtue as a social-political concept, see Hal Cook's article, "Body and Passions: Materialism and the Early Modern State," in this volume.

${ }^{7}$ Daniel T. Rodgers, Contested Truths: Keywords in American Politics since Independence (New York: Basic Books, 1987), pp. 45-79.

${ }^{8}$ On such projects see, e.g., Ken Alder, "French Engineers Become Professionals: Or, How Meritocracy Made Knowledge Objective," in The Sciences in Enlightened Europe, ed. William Clark, Jan Golinski, and Simon Schaffer (Chicago: Univ. of Chicago Press, 1999), pp. 94-125; David D. Bien, "The Army in the French Enlightenment: Reform, Reaction and Revolution," Past Present 85 (1979): 68-98; Roger Hahn, The Anatomy of a Scientific Institution: The Paris Academy of Sciences, 16661803 (Berkeley: Univ. of California Press, 1971); James L. McClellan, Science Reorganized: Scientific Societies in the Eighteenth Century (New York: Columbia Univ. Press, 1985); Jay M. Smith, The Culture of Merit: Nobility, Royal Service, and the Making of Absolute Monarchy in France, 16001789 (Ann Arbor: Univ. of Michigan Press, 1996).

${ }^{9}$ John Adams, Defence of the Constitutions of Government of the United States (1787), reprinted in The Works of John Adams, ed. Charles Francis Adams, 10 vols. (Boston: Little, Brown \& Co., 1850-1856), vol. 4, p. 391, and for more details on Adams's views, pp. 391-8.

${ }^{10}$ As Jefferson explained to Adams in his letter of $28 \mathrm{Oct}$., his proposals at the time of the Constitutional debates (1788-1789) to abolish entails and primogeniture and to establish a comprehensive system of education had not had as their purpose the destruction of all social distinction, but only of the hold of the pseudo-aristocracy in favor of those born into every class who by their own merits should prosper and lead the nation. See Adams-Jefferson Letters (cit. n. 1), pp. 387-92. For further details on Jefferson's system of education, see Thomas Jefferson, Notes on the State of Virginia (1781-1785), reprinted in Portable Thomas Jefferson (cit. n. 6), pp. 193-8. 
produced not complete social leveling, but rather continuous social jostling between the more and less elite, and a consequent deep-seated instability in the social order. ${ }^{11}$ Eighteenth-century writers, however radical their attacks on the privileges of birth and blood, routinely assumed the persistence of a whole range of hierarchies - be it men over women, adults over children, or Europeans over other peoples-whether they saw these stratifications arising on the basis of nature or custom.

Third, Adams believed no less than Jefferson that one of the main reasons complete equality could never be achieved even in the ideal republic was nature: some people were simply better endowed with particular talents or virtues than others, and these superior abilities either entitled them to (in Jefferson's eyes) or helped them to attain (in Adams's view) positions of power in government and influence in civil society. Jefferson celebrated this fact about human nature; indeed he saw such true aristoi as the guardians of the nation's republican legacy and measured the success of the system of government by its ability to place such people in positions of leadership. Adams was warier, finding neither natural nor artificial aristocracy particularly to his liking. But he, too, had to concede that, because individuals were by nature different, distinctions would inevitably emerge in society and some would have power over others. ${ }^{12}$ The rhetorical power of "nature," of course, can scarcely be overemphasized for Enlightenment authors. A touchstone for both natural and moral philosophers, and one of the juncture points for their often separate endeavors, "nature" served as a key means of legitimating claims to knowledge and plans for reform, whether it was the nature of Isaac Newton's Principia (1687) or of Adam Smith's Wealth of Nations (1776). ${ }^{13}$

The move by Jefferson and Adams and other Enlightenment writers to turn to "nature" and link particular distributions of power and influence to certain "natural" facts about human beings is the subject of this essay. Using Jean-Jacques Rousseau's widely renowned exploration of the origins of inequality in human societies to set the stage, I begin by establishing the centrality of the existence of natural human differences to Enlightenment political speculation. I then investigate how people in the eighteenth century understood such differences, focusing on their place within the discourse of mental philosophy, and conclude by examining three kinds of response - typified by the arguments of Claude-Adrien Helvétius, Thomas Paine, and Mary Wollstonecraft - that highlight the variety of ways in which the sciences of human nature and theories of republican governance informed one another in the late eighteenth century. By using the language of talents as a focus, I examine how Enlightenment political writers and human scientists, in the process of theorizing the foundations of civil society and articulating a new understanding of human nature

\footnotetext{
${ }^{11}$ See Alexis de Tocqueville, Democracy in America, 2 vols. (New York: Knopf, 1994), especially vol. 2 (1840), bks. 2 and 3.

${ }^{12}$ See Adams, Defence of the Constitutions of Government of the United States (cit. n. 9), pp. 391-8.

${ }^{13}$ Isaac Newton, The Principia: Mathematical Principles of Natural Philosophy, trans. I. Bernard Cohen and Anne Whitman (Berkeley: Univ. of California Press, 1999); and Adam Smith, An Inquiry into the Nature and Causes of the Wealth of Nations (1776; reprinted, New York: Modern Library, 1994), vol. 1, bk. 1, chap. 2. See also David Carrithers, "The Enlightenment Science of Society," in Inventing Human Science: Eighteenth-Century Domains, ed. Christopher Fox, Roy S. Porter, and Robert Wokler (Berkeley: Univ. of California Press, 1995), pp. 232-70; Peter Gay, The Enlightenment, an Interpretation, 2 vols., vol. 2: The Science of Freedom (New York: Knopf, 1969); Thomas L. Hankins, Science and the Enlightenment (Cambridge: Cambridge Univ. Press, 1985); and Roger Smith, "The Language of Human Nature," in Inventing Human Science, pp. 88-111.
} 
established according to the dictates of nature, elaborated a vision of a social order at once egalitarian and stratified and of human talents and virtues as products of both nature and experience. This connection between understandings of human nature and notions of civil society was so well established that even radical critiques in the name of greater inclusivity - such as those promulgated by Helvétius and Wollstonecraft - had to be couched in terms of individual talents and the rights that could be derived from their possession. The conceptions of political and social order that thus emerged were ones in which openness to the reasoned opinion of all was tempered by the conviction that some, through good education or the gift of nature or both, possessed talents that privileged their voices in the cacophony of public opinion and the struggle for political power.

\section{HUMAN NATURE AND ENLIGHTENMENT GOVERNANCE}

The extent of an individual's talents or virtues had not always been an issue of great importance to either political writers or political actors. They began to cede significance to such characteristics in the latter half of the eighteenth century, when Enlightenment investigations into the foundations of state and society merged with scientific explorations into the fundamentals of human nature and the realities of an increasingly market-oriented consumer society. As a consequence, Enlightenment political writers came to interrogate the very conception of a social order legitimated on the basis of birth and privilege. Few of these authors rejected outright the highly stratified, mostly aristocratic societies they knew so intimately. Far from it. But there was a group of natural philosophers, moral philosophers, and what might anachronistically be called political theorists, ranging from Thomas Hobbes in the early seventeenth century to Thomas Paine in the late eighteenth century (and including all the figures about whom Adams was so chary), who sought to place the foundations of civil and political society on new grounds. To such philosophers and theorists, these grounds seemed anchored in the realities of nature and the dictates of reason, not to mention the experiences of everyday economic life, rather than in the conventions of custom and/or the precepts of Christian religion. ${ }^{14}$

Because they considered hereditary aristocracy to lie at the heart of the socialpolitical structure of the ancien régime, many of these writers, mostly from what has been called the radical wing of the Enlightenment, targeted hereditary aristocracy in their attempts to imagine society reconstituted on a basis that could be deemed "rational." In general, they sought to demonstrate that rule by hereditary aristocracy violated reason because such rule was too susceptible to instability and corruption, the natural result, they suggested, of being unable to ensure that individuals with the appropriate attributes reached positions of power. In place of such an "irrational" approach to governance, some writers argued for a form of democratic republic, one in which they imagined "the people," however construed, as the foundation of the state, and social distinction and hierarchy, to the degree they would persist at all, as based on a rationalized system of merit rather than on the accidents of birth. For

\footnotetext{
${ }^{14}$ As Mary Wollstonecraft remarked: "that the society is formed in the wisest manner, whose constitution is founded on the nature of man, strikes, in the abstract, every thinking being so forcibly, that it looks like presumption to endeavour to bring forward proofs." Mary Wollstonecraft, A Vindication of the Rights of Woman (1792; reprinted, with an introduction by Miriam Brody, London: Penguin Books, 1992), p. 92.
} 
most of these authors exploring the possibilities of republican governance and a republican social order, this meant anchoring the system of merit in human nature, specifically in those attributes of human beings that the writers deemed "naturally" valuable - an individual's virtues and talents.

With the significant exception of John Locke at the very beginning of the period, few of the writers who produced the most important examinations of the foundations for a republican polity were serious students of such entities as virtues or talents. Nonetheless, to all of these authors, a proper understanding of human nature was critical, for "nature" in all of its forms served as their means of grounding their speculations on a new and, in their eyes, much firmer foundation. Most thus paid particular attention to the explanations for the human mind and how it operated that were being developed in England by Locke and his disciples (associationism), in Scotland by the Scottish Common Sense philosophers, and in France by the abbé de Condillac and his followers (sensationalism). These systematic investigations into what would begin, by the end of the eighteenth century, to be termed "psychology," sought to provide an understanding of the operations of the human mind that paralleled those being offered by natural philosophers for the physical world. Basing their work on a form of experiment that had as its object of inquiry the universal human mind, the practitioners of associationism, Scottish Common Sense, and sensationalism turned to the facts of nature - sensations and their combinations - as the means to create an empirical and naturalistic understanding of the human intellect and the knowledge it could produce. ${ }^{15}$ Their "science of mind," because it claimed to be able to determine the fundamental characteristics of human nature, thus seemed to many exploring the emerging "science of republican governance" to be of central relevance. ${ }^{16}$

This connection between the articulations of republican theory and the findings of investigators exploring the nature of the human mind, especially around the issue of talents, has been the subject of only limited historical inquiry. While there have been a number of excellent studies of the historical roots of modern psychology, and of the human sciences more generally, few scholars have examined the specific political implications of the theories and practices of their eighteenth-century subjects. ${ }^{17}$ Michel Foucault and his followers are, of course, important exceptions, but even Foucault proved more interested in macrostructural homologies between the human sciences and the liberal polities than in the detailed connections between the

\footnotetext{
${ }^{15}$ See John Carson, "Minding Matter/Mattering Mind: Knowledge and the Subject in NineteenthCentury Psychology," Stud. Hist. Phil. Biol. Biomed. Sci. 30 (1999): 345-76.

${ }_{16}$ Both terms in quotes are coined in full knowledge that the word "science" was not widely used until the nineteenth century.

${ }^{17}$ See Marina Frasca-Spada, "The Science and Conversation of Human Nature," in Sciences in Enlightened Europe (cit. n. 8), pp. 218-45; Gary Hatfield, "Remaking the Science of Mind: Psychology as Natural Science," in Inventing Human Science (cit. n. 13), pp. 184-230; Ronald Meek, Social Science and the Ignoble Savage (Cambridge: Cambridge Univ. Press, 1976); Sergio Moravia, "The Capture of the Invisible: For a (Pre)History of Psychology in Eighteenth-Century France," J. Hist. Behav. Sci. 19 (1983): 370-8; idem, "The Enlightenment and the Sciences of Man," Hist. Sci. 18 (1980): 247-68; idem, "From Homme Machine to Homme Sensible: Changing Eighteenth-Century Models of Man's Image," J. Hist. Ideas 39 (1978): 45-60; Richard Olson, The Emergence of the Social Sciences, 1642-1792 (New York: Twayne Publishers, 1993); Graham Richards, Mental Machinery: The Origins and Consequences of Psychological Ideas, 1600-1850 (Baltimore: Johns Hopkins Univ. Press, 1992); Roger Smith, "The Background of Physiological Psychology in Natural Philosophy," Hist. Sci. 11 (1973): 75-123; and P. B. Wood, "The Natural History of Man in the Scottish Enlightenment," Hist. Sci. 27 (1989): 89-123.
} 
two. ${ }^{18}$ Most scholars outside the Foucauldian tradition have chosen to explore the historical origins and articulations of various approaches to understanding the nature of the mind and the human being. For example, the wonderful collection of essays in the Christopher Fox, Roy Porter, and Robert Wokler volume Inventing Human Science (1995), though rich in detail and nuance, is oriented more toward laying out the complicated historical trajectories of the human sciences than toward linking those patterns to specific political projects. ${ }^{19}$ More successful in this regard is Simon Schaffer's 1990 essay, "States of Mind: Enlightenment and Natural Philosophy." Wide ranging and suggestive, Schaffer's essay argues that the connection between mind and body in the English Enlightenment was a question as charged politically as it was philosophically, and thereby makes clear the rich rewards to be gained from mining the domain where social theory and explorations of human nature met. ${ }^{20}$

A second approach, largely found in older works, has focused on the place of various strains of eighteenth-century "psychology" in the thought of important American political leaders. Studies of Jefferson, James Madison, Benjamin Rush, and John Witherspoon, for example, have sought to explain how aspects of their political or intellectual outlooks can be traced to the influence of particular approaches to human psychology. ${ }^{21}$ One of the most historically grounded recent pieces in this vein has been Daniel Walker Howe's Making the American Self (1997). ${ }^{22}$ Like such important earlier interpreters of the American Enlightenment as Henry May and Garry Wills, Howe emphasizes the centrality of the Scottish Common Sense philosophers to the intellectual development of the leading American political thinkers. ${ }^{23}$ Howe departs from both May and Wills, however, by stressing the influences of the Scottish form of faculty psychology. In Howe's view, Scottish Common Sense philosophy's commitment to the existence of an innate moral sense and its optimism about the possibilities of human improvement, mixed with its depiction of a continuous struggle between reason and the emotions, were relied on not only by Jefferson but by the authors of the Federalist Papers-Madison, Alexander

\footnotetext{
${ }^{18}$ See, e.g., Michel Foucault, Madness and Civilization: A History of Insanity in the Age of Reason, trans. Richard Howard (New York: Vintage Books, 1988); and idem, Discipline and Punish: The Birth of the Prison, trans. Alan Sheridan (New York: Vintage Books, 1979).

${ }^{19}$ See particularly the essays by Smith, "Language of Human Nature" (cit. n. 13), and Hatfield, "Remaking the Science of Mind" (cit. n. 17).

${ }^{20}$ Simon Schaffer, "States of Mind: Enlightenment and Natural Philosophy," in The Language of Psyche: Mind and Body in Enlightenment Thought, ed. George S. Rousseau (Berkeley: Univ. of California Press, 1990), pp. 233-90.

${ }^{21}$ See, e.g., Donald J. D'Elia, "Benjamin Rush, David Hartley, and the Revolutionary Uses of Psychology," Proc. Amer. Phil. Soc. 114 (1970): 109-18; Peter J. Diamond, "Witherspoon, William Smith, and the Scottish Philosophy in Revolutionary America," in Scotland and America in the Age of Enlightenment, ed. Richard B. Sher and Jeffrey R. Smitten (Princeton, N.J.: Princeton Univ. Press, 1990), pp. 115-32; Ronald Hamowy, “Jefferson and the Scottish Enlightenment," William Mary Quart. 36 (1979): 503-23; Ralph L. Ketcham, “James Madison and the Nature of Man," J. Hist. Ideas 19 (1958): 62-76; Patricia S. Noel and Eric T. Carlson, "The Faculty Psychology of Benjamin Rush," J. Hist. Behav. Sci.9 (1973): 369-77; and Robert G. Weyant, "Helvétius and Jefferson: Studies of Human Nature and Government in the Eighteenth Century," J. Hist. Behav. Sci. 9 (1973): 29-41.

${ }^{22}$ Daniel Walker Howe, Making the American Self: Jonathan Edwards to Abraham Lincoln (Cambridge, Mass.: Harvard Univ. Press, 1997), especially pp. 48-103.

${ }^{23}$ Garry Wills, Inventing America: Jefferson's Declaration of Independence (New York: Vintage, 1979), especially pp. 167-255; Henry F. May, The Enlightenment in America (New York: Oxford Univ. Press, 1976). See also Morton G. White, The Philosophy of the American Revolution (New York: Oxford Univ. Press, 1978).
} 
Hamilton, and John Jay - and proved critical constituents of their visions of the kind of politics and society possible in a democracy.

Taken together, such works on the relations between philosophy and political theory have established conclusively the importance of Enlightenment investigations into human nature for a full understanding of how some of the major figures in the American revolutionary era articulated their ideas about republican democracy. In her recent book, A History of the Modern Fact (1998), Mary Poovey has broadened this story in important ways by arguing that a key problem for eighteenth-century Britain was to produce the self-governing liberal subject within the emerging market system, a citizen needing to be much more regulated by the self than by the state. ${ }^{24}$ A form of moral philosophy strongly indebted to the methods of natural philosophy, she maintains, became a central knowledge project in Britain then, and did so because it proved a valuable way to theorize, and bring into actuality, the self required for a liberal social-political order and consumer-driven economy. "To appreciate the epistemological contributions of eighteenth-century experimental moral philosophy," Poovey observes, "we need to understand that it was a practice devised in the image of natural philosophy but designed as an account of human motivation and thus, indirectly at least, as an instrument of liberal governmentality." 25

Poovey's contention that a new kind of social order required a new kind of citizen and was interwoven with a new way of understanding the mind is suggestive. In this article, I take up her problematic by examining a related phenomenon: how notions of mind and the emerging language of talents informed one another. ${ }^{26}$ Except in the work of Gordon Wood, little attention has been paid to the political valence of the "talents" half of one of the most common phrases in republican political rhetoric throughout the Atlantic community: "virtues and talents." ${ }^{27}$ And even Wood, as thoughtful as his analysis is, has not examined the ways in which the language of talents was infused with notions of human nature being shaped, in part, by philosophers on both sides of the English Channel. Because the major political and philosophical treatises were widely distributed and even more broadly known among the educated elite, I do not keep tightly in this essay to national borders or chronology. Rather, by tracing out a number of lines in the development of this language of talents and how it drew together systematic explorations of mind and theories of governance, I seek to understand what work the notion of talents was performing for the advocates of republicanism during the eighteenth century, particularly in terms of limiting some of the (theoretical anyway) egalitarian possibilities inherent in the vision of a republican society founded on virtue. Because these foundational speculations were at once about the remaking of political culture and of civil society, not to mention the managing of the tension between them, this essay examines how

\footnotetext{
${ }^{24}$ Mary Poovey, A History of the Modern Fact: Problems of Knowledge in the Sciences of Wealth and Society (Chicago: Univ. of Chicago Press, 1998). See also Michel Foucault, The Foucault Effect: Studies in Governmentality, with Two Lectures and an Interview with Michel Foucault, ed. Graham Burchell, Colin Gordon, and Peter Miller (Chicago: Univ. of Chicago Press, 1991).

${ }^{25}$ Poovey, History of the Modern Fact (cit. n. 24), p. 175.

${ }^{26}$ Also very helpful in thinking through my approach to the issues I explore in this article was Carroll Smith-Rosenberg, "Dis-Covering the Subject of the 'Great Constitutional Discussion,' 17861789," J. Amer. Hist. 79 (1992): 841-73.

${ }^{27}$ For an extended discussion of the political ramifications of "talents," see Gordon S. Wood, The Radicalism of the American Revolution (New York: Knopf, 1992), especially pp. 229-43.
} 
the science of human nature served as a resource for the understanding of both, and, indeed, as Poovey has argued, was one of the means instrumental in keeping them closely allied.

\section{FROM ROUSSEAU'S EXCURSION TO THE REVOLUTION'S COMPACT: SITING THE NATURAL INEQUALITIES}

One of the most striking and public articulations of the vision of republican civil society as derived from a combination of democracy and merit, with human nature at the center, was provided in Article VI of the Declaration of the Rights of Man and of Citizen (1789), which set out the basic compact between the people and the government on which the new French republic was to be established:

VI. Law is the expression of the general will; all citizens have the right to concur personally, or through their representatives, in its formation; it must be the same for all, whether it protects or punishes. All citizens, being equal before it, are equally admissible to all public offices, positions, and employments, according to their capacity, and without any other distinction than that of virtues and talents. ${ }^{28}$

As a succinct summation of the tangle of often antithetical ideas at the center of late-eighteenth-century political discourse on both sides of the Atlantic, Article VI had few rivals. In just one short paragraph, it suggested that the people were the source of all law, that some sort of representative democracy was the preferred form of government, that law should apply the same standards to all citizens, and that merit was the only source of distinction. Article VI captured some of the tensions between the general or communal and the individual, between governmental power and personal liberty, and between sameness, equality, and difference, while at the same time occluding the many everyday distinctions of gender, class, and nationality assumed under the penumbra "citizen."

Article VI's most telling feature, however, with regard to the place of human nature in the discourse of civil society, was that distinctions between individuals remained fundamental, albeit resting on a new footing - that of virtues and talents. In this regard, Article VI was characteristic of late-eighteenth-century political writing in general. Desiring to construct a state founded on rational principles, believing that the original compact creating society was fashioned among free (white male) individuals without distinctions of rank or wealth or birth, hostile to the notion of binding the future to the traditions of the past, and convinced that some rational mechanism for distributing social roles and political power was crucial, Enlightenment political theorists seized on merit as the rational counterweight to demands for universal rights. ${ }^{29}$ All citizens might have an equal opportunity to vie for political power and an equal voice in selecting their leaders. But, the theorists contended, the "reality" that government and the economy required particular talents and virtues not necessarily distributed evenly among all members of the populace meant that

28 "The Declaration of the Rights of Man and Citizen" (1789), reprinted in The Portable Age of Reason Reader, ed. Crane Brinton (New York: Viking, 1956), p. 201.

${ }^{29}$ See, e.g., Thomas Paine, Rights of Man (1792; reprinted, with an introduction by Eric Fouer, New York: Penguin Books, 1985). 
certain individuals would be better suited to positions of power than others ${ }^{30}$ In a world where distinctions of birth still constituted the primary means by which the social hierarchy was established and justified, the idea of granting political leadership and apportioning occupations and social rewards primarily on the basis of an individual citizen's attributes was in many ways revolutionary. Nevertheless, while Article VI and most advocates of republican politics were firmly committed to the claims of universal rights - at least for white, propertied males - in the political and the public spheres, few desired to level all social distinctions and to create a society that was radically egalitarian. ${ }^{31}$ This tension, in fact, between the allocation of rights and the privileges of merit, and thus between the languages of equality and of difference, constituted one of the major dynamics of eighteenth-century debate about how to constitute civil society. And it was a debate that pushed issues of the nature of virtues and talents to center stage.

While Enlightenment authors were often quite vigorous in their attempts to specify exactly what they meant by "virtues," they were much more circumspect about the word "talents." 32 Almost always used in the plural, "talents" was often connected with other words - such as "abilities" or "capacities" or "faculties" — signifying some set of attributes that different individuals might possess to different degrees. ${ }^{33}$ Whether these differences were many or few, whether they resulted from education or nature, whether they were a product of heredity or chance, however, were all issues on which there was pronounced disagreement. In the main, the specific variations seemed to matter less than the general signification of the term: an avowedly natural criterion by which human differences could be delineated and discussed. "Talents" was one way of speaking like a democrat and yet still being able to justify social distinctions, though ones based on decidedly different grounds than the heretofore standard differentiations according to birth and tradition. One consequence of this attempt to anchor such a language of merit in the natural attributes of human beings, however, was the creation of a link between the newly emerging sciences that sought to define and explore human nature and republican speculations about the structure of state, society, and economy. If Enlightenment authors justified distinctions and even stratifications in republican civil society and allocations of power on the basis of differences in individual virtues and talents understood as natural objects, then scientific investigations able to substantiate the reality of such

\footnotetext{
${ }^{30}$ Thomas Jefferson's proposal for a plan of education for the state of Virginia, for example, was predicated on educating just such an elite of the most talented. See Thomas Jefferson, Notes on the State of Virginia (cit. n. 10), pp. 193-8.

${ }^{31}$ Gordon Wood observes that "equality was thus not directly conceived of by most Americans in 1776, including even a devout republican like Samuel Adams, as a social leveling." Wood, Creation of the American Republic (cit. n. 5), p. 70. Jean Starobinski notes much the same of Rousseau: "he does not ask for social leveling but simply for a proportioning of civic inequality to the natural inequality of talents." Jean Starobinski, Jean-Jacques Rousseau: Transparency and Obstruction, trans. Arthur Goldhammer (Chicago: Univ. of Chicago Press, 1988), p. 302.

${ }^{32}$ There is an extensive literature on the concept of "virtue" in the early modern period. See, e.g., Ruth H. Bloch, "The Gendered Meanings of Virtue in Revolutionary America," Signs 13 (1987): 37-58; Carol Blum, Rousseau and the Republic of Virtue: The Language of Politics in the French Revolution (Ithaca, N.Y.: Cornell Univ. Press, 1986); James T. Kloppenberg, "The Virtues of Liberalism: Christianity, Republicanism, and Ethics in Early American Political Discourse," J. Amer. Hist. 74 (1987): 9-33; Pocock, Machiavellian Moment (cit. n. 5); Charles Royster, “The Nature of Treason': Revolutionary Virtue and American Reactions to Benedict Arnold," William Mary Quart. 36 (1979): 163-93; and Wood, Creation of the American Republic (cit. n. 5).

${ }^{33}$ For more, see Wood, Radicalism of the American Revolution (cit. n. 27).
} 
attributes and give them form could shape the horizon of possibilities for the new societies Enlightenment political thinkers were theorizing. The widespread preoccupation with nature and reason, along with the development of a growing class of people defined more by their accomplishments than by their birth, spurred many of these authors to imagine restructuring the polity according to such principles. Their works served simultaneously to write certain speculations about human nature into the very heart of the republican project and to orient the emerging human sciences toward embracing those social formations most consonant with the developing notions of the republican citizen, the enlightened society, and the self-interested economic actor.

However, as the Jefferson-Adams debate reveals, the eighteenth century had no single canonical interpretation of the relations between the structure of republican societies, the language of merit, and understandings of the natural characteristics of human beings. Thus there are any number of places to begin an investigation into the relations between notions about the fundamental characteristics of the human understanding and the proper constitution of the social order. None, however, may be more instructive than Jean-Jacques Rousseau's Discourse on the Origin and Foundations of Inequality among Men (1755), his first serious use of the state of nature to examine contemporary civilization. ${ }^{34}$ In a manner similar to Hobbes, Locke, and numerous philosophers before him, Rousseau set out to discover the origins of human society by taking his readers on a journey to the state of nature to discover humanity in its pristine "original condition" and then back to civilization to describe the slow evolution of the state of nature into the state of society. His main point was a deceptively simple one: in a state of nature, outside the "corrupting" influences of civilization, the natural condition of human beings, or at least the adult males of the species, was to be free, independent, and equal. As Rousseau would remark a few years later in a famous passage from On the Social Contract (1762), "Man is born free, and everywhere he is in chains." 35

The very title of his discourse suggests Rousseau's quest: to determine the source of the extreme and extensive inequalities he found manifest in eighteenth-century French society. The Discourse on Inequality was a detailed argument that civilization itself produced these differences and that a properly organized society could eliminate many, if not most, of them. He thus began the work of imagining a new civil order based on the free association of equals; seven years later, he would present a more elaborate version of this new order in On the Social Contract. Rousseau, however, acknowledged the existence of one significant exception in his account, one that made him uneasy throughout. His exploration of the state of nature convinced him that inequality had not one source, but two-civilization and nature itself:

I conceive of two kinds of inequality among the human species, one I call natural or physical, because it is established by nature and consists of differences in age, health, physical strength, and qualities of mind [esprit] or soul; the other may be called moral or political inequality, because it depends upon a kind of agreement and is established or at least authorized, by the consent of men. The latter consists of the different privi-

\footnotetext{
${ }^{34}$ Jean-Jacques Rousseau, Discourse on the Origin and Foundations of Inequality among Men (1755), reprinted in Rousseau's Political Writings, ed. Alan Ritter and Julia Conaway Bondanella and trans. Julia Conaway Bondanella (New York: W. W. Norton, 1988).

${ }^{35}$ Rousseau, On the Social Contract (1762), reprinted in Rousseau's Political Writings (cit. n. 34), p. 85 .
} 
leges that some enjoy to the detriment of others, such as being more wealthy, more honored, more powerful than they, or even to make themselves obeyed by them. ${ }^{36}$

This second type of inequality, being wholly reliant on the existence of civilization, could not be found in the state of nature. But the first, which included the natural, as opposed to the developed, inequalities of mind, could. Rousseau did argue that human beings in a state of nature were essentially equal, concluding that however great the differences might be between one person and another, they mattered little outside the confines of civilization. Equality prevailed in nature, he believed, because there was scant opportunity in the day-to-day struggle to survive for differences to manifest themselves, because the solitary mode of life characteristic in nature prevented whatever differences might arise from being noticed, and because without civilization there was no chance for rudimentary differences to be further developed and passed on to others. ${ }^{37}$ With the arrival of even the most rudimentary forms of civil society, however, everything changed. Able to compare themselves to each other, individuals discovered that their talents differed, that two people engaged in the same task did not necessarily perform at the same level. Some were better than others. Not just difference but, in Rousseau's view, inequality became manifest, and with this inequality came further pressures for the development of civilization and the fashioning of social hierarchies:

Things in this state might have remained equal, if talents had been equal. . . . [However,] the strongest did more work; the most skillful turned his to better advantage; the most ingenious found ways to curtail his work; the farmer needed more iron, or the blacksmith more wheat; and, by working equally, one earned a great deal, while the other had barely enough to live on. Thus, natural inequality spreads imperceptibly along with contrived inequality, and the differences among men, developed by differences in circumstances, make themselves more obvious, more permanent in their effects, and begin, in the same proportion, to influence the fate of individuals. ${ }^{38}$

There are two important points to be noted about Rousseau's juxtaposition of the state of nature with the state of society. First, he posited a certain irreducible naturalness about variations in human mental and physical characteristics. Unlike the inequalities of wealth, family, and power, differences of physical constitution and quality of mind persisted in Rousseau's account even outside the nurture of civilization. They were, in a sense, bedrock attributes of human nature. And second, differences in these "natural" human talents could have profound social consequences. They formed the basis for the development of many of the inequalities and hierarchies that Rousseau found most characteristic of, and deplorable about, civilization.

Rousseau's analysis of the origins of human differences was in no way atypical of Enlightenment discussions of human nature. From such midcentury philosophers as David Hartley and the abbé de Condillac to late-century political writers William Godwin, Mary Wollstonecraft, and Thomas Paine, not to mention Jefferson, there was a common tendency at least among the more liberal to radical Enlightenment authors to depict human mental and physical characteristics as somehow more fundamental, more real, and ultimately more natural than the "accidents" of birth,

\footnotetext{
${ }^{36}$ Rousseau, Discourse on Inequality (cit. n. 34), pp. 8-9.

${ }^{37}$ Ibid., pp. 31-2.

${ }^{38}$ Ibid., pp. 41-2.
} 
wealth, or class. ${ }^{39}$ While there might have been intense, and important, disagreement over exactly what these essential human attributes were, whence they were derived, and whether some were more important than others, there was little dispute that such characteristics were anchored in "nature" and that this connection had significant political implications. This is the first point to draw from Rousseau's investigation into the sources of human inequality: that he linked the articulation of civil society to conceptions of the nature of human beings, and thus gave speculations about mind and behavior a particular political and social valence..$^{40}$

At the same time, Rousseau's assertion that life in the state of nature revealed the existence of inequality as fundamental to human nature suggested that those who dreamed of a society shorn of all marks of distinction and difference were misguided. While the social contract might well be fashioned out of independent agents coming together for mutual good, the result would not be the simple equality of the republican agora. Though various political rights might be distributed equally among those deemed full citizens, political power and civil society would continue to be defined by stratifications and differences. Some people would naturally be better than others, be it at farming or blacksmithing or governing or perhaps reasoning itself, and these superior abilities could readily be translated into political and social advantage. Indeed, one of the attractions of such a conception of human nature to Rousseau and many other philosophes-almost all members of the middling classes or lower-may have been precisely that it confirmed their own senses of deserving to be rewarded for having minds far superior to the common run of humankind. ${ }^{41}$ Rousseau himself, having articulated the problem, provided little in the way of a solution in Discourse on Inequality and indeed was still wrestling with its implications in On the Social Contract and Emile (1762). Others were equally engaged, confronted by the twin puzzles of first understanding just what the talents were and how natural they might be, and then trying to imagine a system of society and governance that would accommodate these fundamental characteristics of human nature while still providing space for the demands of equality.

\section{"FASHION HAS INTRODUCED AN INDETERMINATE USE OF THE WORD 'TALENTS'”}

In his first major work, the Enquiry Concerning Political Justice and Its Influence on Morals and Happiness (1793), William Godwin-high on Adams's list of most suspect Enlightenment political authors-boiled his principle for the proper organization of society and government down to its essence: "The thing really to be desired, is the removing as much as possible arbitrary distinctions, and leaving to tal-

\footnotetext{
${ }^{39}$ As James Madison argued in Federalist No. 57: "Who are to be the electors of the federal representatives? Not the rich, more than the poor; nor the learned, more than the ignorant; not the haughty heirs of distinguished names, more than the humble sons of obscure and unpropitious fortune.... No qualification of wealth, of birth, of religious faith, or of civil profession is permitted to fetter the judgment or disappoint the inclinations of the people." Alexander Hamilton, James Madison, and John Jay, The Federalist Papers (New York: Mentor Books, 1961), pp. 350-1.

${ }^{40}$ Michel Foucault has elaborated on the consequences of this point at length in Discipline and Punish (cit. n. 18).

${ }^{41}$ I am indebted to my colleague Dena Goodman for this point. For more on the culture of the philosophes, see Dena Goodman, The Republic of Letters: A Cultural History of the French Enlightenment (Ithaca, N.Y.: Cornell Univ. Press, 1994).
} 
ents and virtue the field of exertion unimpaired."42 Like Jefferson and many other republican theorists at the end of the century, Godwin was clear on this much: merit should be preeminent and talents and virtues were integral to any conception of merit. Such writers were much less clear, however, about two related issues: First, just what constituted talents and virtues and who decided? Second, how exactly did these attributes originate and vary, and could they be altered? While late-eighteenthcentury authors would invoke both terms frequently, they rarely attempted to provide precise definitions. Instead, "talents" especially tended to be used mainly as a placeholder, able to suggest a multitude of positive characteristics without being restricted to any particular denotation. In Rights of Man, for example, Paine littered his text with references to talents and how government required a variety of them for its successful operation. At the same time, however, he provided few concrete examples and never a specific definition. He simply assumed that his readers would know what he meant by the term and would themselves fill in the relevant attributes. ${ }^{43}$

Nevertheless, given the centrality of talents to the project of determining the boundaries that human nature set on the making of republican government and society, the term must be defined a bit more precisely. Paine did provide one important insight in this regard: he often suggested in Rights of Man that talents were intimately connected with powers or faculties of the mind, and that they were the critical variables in choosing good leaders. ${ }^{44}$ Contemporary dictionaries corroborate this sense of the word. Samuel Johnson, for example, defined "talent" in his A Dictionary of the English Language (1755) as "faculty; power; [or] gift of nature," a meaning little different from that provided by Le Grand vocabulaire François (1773) and the Dictionnaire de l'académie Françoise, nouvelle édition (1786), both of which stated that "talent" figuratively referred to a "gift of nature, natural disposition or aptitude for certain things, capacity, [or] ability." ${ }^{45}$ As both the English and French dictionaries suggested, talent was taken to refer to some sort of potential for superior achievement, with the strong implication in both languages that one was born with it rather than developed it. In addition, the French dictionaries suggested, although only slightly, that talent referred to characteristics that had specific external manifestations, particularly those involving the ability to accomplish a particular task. Le Grand vocabulaire François, for example, distinguished between qualities and talents-qualités made one good or bad, talents useful or amusing - and between genius and talents-génie, it noted, was more interior and partook of invention, talent more exterior and provided for brilliant execution. ${ }^{46}$

\footnotetext{
${ }^{42}$ William Godwin, Enquiry Concerning Political Justice and Its Influence on Morals and Happiness, 3 vols., ed. F. E. L. Priestley (1793; reprinted, with an introduction by F. E. L. Priestley, Toronto: Univ. of Toronto Press, 1946), vol. 1, p. 147.

${ }^{43}$ Paine's closest attempt at a definition of talents may have been the following: "if we examine, with attention, into the composition and constitution of man, the diversity of his wants, and the diversity of talents in different men for reciprocally accommodating the wants of each other, his propensity to society, and consequently to preserve the advantages resulting from it, we shall easily discover, that a great part of what is called government is mere imposition." Paine, Rights of Man (cit. n. 29), pp. 163-4.

44 Ibid., pp. 175-6.

${ }^{45}$ Samuel Johnson, A Dictionary of the English Language (London: W. Strahan, 1755), s.v.; Le Grand vocabulaire François (Paris: n. p., 1773), vol. 27, pp. 324-5; and Dictionnaire de l'Académie Françoise, nouvelle édition (Nismes: Pierre Beaume, 1786), vol. 2, p. 554.

${ }^{46}$ Le Grand vocabulaire François (cit. n. 45), vol. 27, pp. 324-5. On genius in relation to natural philosophy in the late eighteenth and early nineteenth centuries, see Simon Schaffer, "Genius in
} 
In the world of eighteenth-century dictionaries, therefore, "talents" denoted particular attributes of mind or body, probably present from birth, with at least a hint in French that the term referred more to externalized accomplishments than to internal potentials. Left at this level of generality, "talents" could refer to just about any operation that an individual could successfully perform. Indeed Adams exploited just this openness in the word when responding to Jefferson's long missive on the natural aristocracy:

We are now explicitly agreed, in one important point, vizt. That 'there is a natural Aristocracy among men; the grounds of which are Virtue and Talents.' ... But tho' We have agreed in one point, in Words, it is not yet certain that We are perfectly agreed in Sense. Fashion has introduced an indeterminate Use of the Word 'Talents.' Education, Wealth, Strength, Beauty, Stature, Birth, Marriage, graceful Attitudes and Motions, Gait, Air, Complexion, Physiognomy, are Talents, as well as Genius and Science and learning. ${ }^{47}$

Adams, of course, was having a bit of fun at Jefferson's expense by twitting his faith in the judgment of the common citizen and idealized vision of democratic politics. Nonetheless, in at least two regards Adams's remarks are quite revelatory. First, his very acknowledgment of the political implications of the meaning of talents suggests the extent to which aspects of human nature had become central elements in republican discourse by the end of the eighteenth century. And second, Adams's cynicism highlighted a critical feature of Jefferson's conception of talents: he restricted it to those attributes he deemed most essential to the continued flourishing of a democratic republic-genius, science, and learning. In this regard, indeed, Jefferson was not alone. If "science" were dropped or broadened to denote systematic thinking of any sort, and if "reason" were specifically included, then Jefferson's version of talents would come very close to what was routinely assumed about politics and society by the whole cadre of Enlightenment theorizers that Adams held in such contempt. All considered themselves to be the final judges of what was, and was not, a true talent, and most sought, in one form or another, to legitimate their own right to speak authoritatively by establishing that talents such as theirs were the ones of critical importance.

Mary Wollstonecraft, another leading light in Godwin's circle of radical Enlightenment authors, clearly manifested this usage of talents in her work. Desirous of establishing a role for women in democratic republics, Wollstonecraft was concerned throughout $A$ Vindication of the Rights of Woman (1792) with delineating which mental attributes made a good republican citizen and which did not. Beauty, cunning, coquettishness, sensualism, and dissimulation-indeed most of the skills commonly associated, as she pointed out, with both women and aristocrats-were not abilities that had merit in republics. ${ }^{48}$ Rather, she valorized talents that gave evidence of independent minds well stocked with experience and knowledge, of

Romantic Natural Philosophy," in Romanticism and the Sciences, ed. Andrew Cunningham and Nicholas Jardine (Cambridge: Cambridge Univ. Press, 1990), pp. 82-98; and Richard Yeo, "Genius, Method, and Morality: Images of Newton in Britain, 1760-1860," Sci. Context 2 (1988): 257-84.

${ }^{47}$ Adams to Jefferson, 15 Nov. 1813, Adams-Jefferson Letters (cit. n. 1), pp. 397-8.

${ }^{48}$ Wollstonecraft, Vindication (cit. n. 14), especially chap. 4. 
reasoning faculties finely sharpened, of passions and interests dominated by reason, and of politeness, modesty, and concern for the good of the whole. ${ }^{49}$ These attributes accorded well with Jefferson's ideal of the independent yeoman farmer and Robespierre's of the virtuous citizen - "male" characteristics, in the main, and specifically those attributed to hardworking males of the middling sort, especially those who had by means of such talents achieved success in some aspect of public or economic life. "Abilities and virtues," Wollstonecraft noted, "are absolutely necessary to raise men from the middle rank of life into notice, and the natural consequence is notorious - the middle rank contains most virtue and abilities." ${ }^{50}$

In a democratic republic, therefore, as even Adams would have agreed, not all talents deserved to be accorded merit, only those that contributed in some way to an individual's wisdom or virtue. And those were talents that, at least for the philosophers theorizing the republican project, involved the ability to acquire information and to generalize from it, to rise above local prejudices, and to channel the passions and desires according to the dictates of reason. James Madison explained simply the interrelations of democratic theory and (appropriate) human capacities in Federalist No. 58 (1788) when discussing the proper size for the House of Representatives. Those "of limited information and of weak capacities," he maintained, were most likely to be susceptible to demagogues and thus to allow a democratic republic to be transformed into an oligarchy. Republics, Madison concluded, required representatives who were knowledgeable and intellectually talented in order to survive. ${ }^{51}$

Having fashioned a central role in republican discourse for individuals with talents, and having loosely indicated what general sorts of characteristics these were and their own right to settle the question, Enlightenment political theorists confronted one further problem as they developed their language of merit: the explanation of where talents came from, why some people had more of them to a higher degree than others, and why that mattered. The question of origins and differential abilities, crucial to the explanation of just how egalitarian a republic could theoretically be, generated little consensus among those who explored it. Some theorists argued for the primacy of native endowment, others education; some believed that heredity played an essential role, others an inconsequential one; some distinguished between individuals and groups, others did not. The differences were enormous and extremely varied, although there were certain commonalities: most discussions of the origins of talent among liberal to radical Enlightenment authors focused on the polarities, and many were couched in terms of particular theories of the operations of the human mind.

Probably the most important distinction eighteenth-century writers fastened on in analyzing the origins of talent was that between talents as gifts of nature and talents as products of education. As we have seen, the definitions of the term provided by contemporary English and French dictionaries laid heavy emphasis on the "gift of nature" sense of "talent," suggesting that talents were faculties or capabilities present from birth. Writers as diverse as Denis Diderot, Pierre-Jean-Georges Cabanis, Wollstonecraft, James Mill, Paine, and Jefferson all shared this understanding of the term,

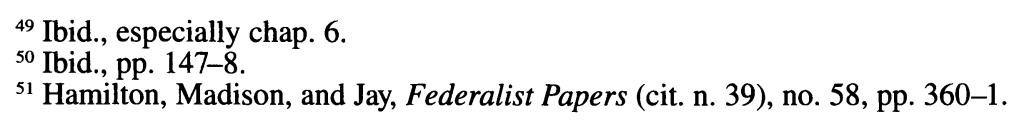


assuming that education could sharpen or dull an individual's talents but could not create them or develop them beyond a certain point. This belief lay at the heart of both Jefferson's ideal of rule by a natural aristocracy and Paine's celebration of the potentials of republican democracy.

Counterposed to this explanation of talents as primarily the product of nature stood those explanations placing equal or greater weight on the power of education. Virtually all writers, no matter where they fell on the nature-education spectrum, conceded that external influences could have some significant effect on human talents. The essence of Wollstonecraft's argument in Vindication, for example, was that women mostly lacked the abilities required of republican citizens because they had been denied the necessary training. Proper education, she asserted, would show that women as a group possessed the same kinds of faculties as men, though whether to the same degree she left an open question, at least rhetorically. ${ }^{52}$ What she did not deny, however, was that individuals, male or female, naturally differed in the types of talents with which they were endowed and the degree to which development was possible. "But, treating of education, or manners," Wollstonecraft remarked, "minds of a superior class are not to be considered, they may be left to chance; it is the multitude, with moderate abilities, who call for instruction, and catch the colour of the atmosphere they breathe." 53

Other Enlightenment writers - including Helvétius, Antoine Louis Claude Destutt de Tracy, Smith, Joseph Priestley, Godwin, and Benjamin Rush-were willing to push the power of education much further, conceding to it not just some influence but, in fact, a definitive role. For these authors the mind was, in Locke's words, a tabula rasa, empty of all ideas and potentials before being filled by the set of experiences that defined an individual's life. The arguments that Godwin presented in Enquiry Concerning Political Justice are an excellent illustration of what might be called the "environmentalist" position. He specifically attacked the physiological explanations of human abilities on at least three grounds. First, he maintained that while individuals might indeed differ to some degree in their original endowments, those differences were not particularly significant. "But, though the original differences of man and man be arithmetically speaking something, speaking in the way of a general and comprehensive estimate they may be said to be almost nothing." ${ }^{4}$

Second, he completely reversed the notion that physiological characteristics, such as skull size, might in some sense be the causes of differences in powers or abilities by suggesting that human physiognomy was plastic and was actually largely shaped by individual action. ${ }^{55}$ And third, Godwin rejected the notion that faculties or capabilities were directly heritable. In place of native endowment, Godwin emphasized the enormous powers of education: "the question whether the pupil shall be a man

\footnotetext{
52 "If women are by nature inferior to men," Wollstonecraft argued, "their virtues must be the same in quality, if not in degree.” Wollstoncraft, Vindication (cit. n. 14), p. 108.

${ }^{53}$ Ibid., p. 162.

${ }^{54}$ Godwin, Enquiry (cit. n. 42), vol. 1, pp. 42-3.

55 "It is not improbable, if it should be found that the capacity of the scull of a wise man is greater than that of a fool, that this enlargement should be produced by the incessantly repeated action of the intellectual faculties, especially if we recollect of how flexible materials the sculls of infants are composed, and at how early an age persons of eminent intellectual merit acquire some portion of their future characteristics. In the mean time it would be ridiculous to question the real differences that exist between children at the period of their birth.” Ibid., p. 38 .
} 
of perseverance and enterprise or a stupid and inanimate dolt, depends upon the powers of those under whose direction he is placed. . . . [T] here are no obstacles to our improvement, which do not yield to the powers of industry." 56 Godwin summed up nicely the fundamental precept underlying the arguments of those writers most committed to explaining human talents on the basis of education. Negating the importance of an individual's original endowments, if indeed such entities were presumed to exist, a number of authors maintained that while individuals and groups did differ, experience alone created the differences. ${ }^{57}$

Not surprisingly, writers such as Godwin who emphasized the power of education in shaping individual talents had little interest in, and provided little role for, the actions of heredity in determining what abilities an individual manifested and to what degrees. But even some of those writers who adopted a more physiological approach to the origin of an individual's talents also gave short shrift to strictly hereditarian explanations of the appearance of natural capacities. Paine, for example, relied on a quite widespread conception of heredity when he remarked in Rights of Man:

Experience, in all ages, and in all countries, has demonstrated, that it is impossible to control Nature in her distribution of mental powers. She gives them as she pleases. Whatever is the rule by which she, apparently to us, scatters them among mankind, that rule remains a secret to man. It would be as ridiculous to attempt to fix the hereditaryship of human beauty, as of wisdom. Whatever wisdom constituently is, it is like a seedless plant; it may be reared when it appears, but it cannot be voluntarily produced. There is always a sufficiency somewhere in the general mass of society for all purposes; but with respect to the parts of society, it is continually changing its place. ${ }^{58}$

Not that Paine's was the only approach to the issue of heredity. Jefferson and Adams, in their correspondence about natural aristocracy, believed just as certainly that talents could be bred, agreeing that desirable characteristics could be produced in humans if they married with the same attention to lineage as was employed in the mating of sheep. ${ }^{59}$ Physician Benjamin Rush, though one of the most vociferous American advocates of the transformative power of education, also came to adopt something of a hereditarian stance, speculating that heredity might in the end prove to be the most significant factor in the apportionment of talent. "It is possible, the time may come," Rush speculated, "when we shall be able to predict, with certainty, the intellectual character of children by knowing the specific nature of the different intellectual faculties of their parents." 60

What is most striking about Enlightenment discussions of heredity is that there was no orthodox position. As much intellectual respectability lay in denying the power of heredity as endorsing it, and a vast array of intermediate positions, involving

\footnotetext{
56 Ibid., p. 44.

${ }^{57}$ On this general issue, see Henry Vyverberg, Human Nature, Cultural Diversity, and the French Enlightenment (New York: Oxford Univ. Press, 1989).

${ }_{58}$ Paine, Rights of Man (cit. n. 29), p. 175.

${ }^{59}$ See Jefferson to Adams, 28 Oct. 1813, Adams-Jefferson Letters (cit. n. 1), pp. 387-92.

${ }^{60}$ Benjamin Rush, "On the Influence of Physical Causes in Promoting an Increase in the Strength and Activity of the Intellectual Faculties of Man" (1799), reprinted in Two Essays on the Mind (New York: Brunner/Mazel, 1972), p. 119.
} 
belief in the inheritance of acquired characteristics and/or in the powerful effects of environmental forces acting on the child while in the womb, were both perfectly acceptable and widely endorsed. ${ }^{61}$ With no expert view conceded authority on the subject, eighteenth-century writers were largely free to construct the hereditarian dimensions of human talents according to their own experiences and understandings of heredity's operations. As a result, the writers advanced a multiplicity of views, and as a group they no more accorded talents a specific implication with regard to heritability than they did with regard to physiology.

The consequences of such an open-ended understanding of human heredity for notions of republican governance were twofold. On the one hand, individual republican theorists still had to wrestle with their own ideas about the heritability of talents, the evidence that would support their positions, and the implications of their beliefs for their conceptions of a functioning republic. Paine's vision of a republic hierarchically organized according to talent but founded on equal opportunity for all, for example, was deeply dependent on his particular understanding of the nature of talents and how they were acquired. Different "facts" about heredity might have resulted in a much different theory of the social-political order. On the other hand, the variety of credible approaches to the question of the heritability of talents meant that a number of different visions of republican governance could be brought into accord with the truths of nature. Science might dictate the terms, but much depended on which rendering of the science of human nature an author accorded credence.

\section{POLITICAL THEORY MEETS MENTAL PHILOSOPHY}

Given this confusion of possibilities, many eighteenth-century theorists, when forced to attend to the issue of the origins and nature of the human talents, turned to the precepts of mental philosophy to buttress their speculations. For some, what beckoned was the ancient language of the "faculties," Aristotelian in its origins, though updated especially as a part of the flowering of mental philosophy during the Scottish Enlightenment. Within the understanding of the Scottish Common Sense school, talents were faculties believed to be either present from birth or developed through education and exercise. ${ }^{62}$ For a growing minority of authors, however, this approach seemed problematic. Helvétius, Godwin, Rush, Diderot, and Cabanis, among others, sought to ground their political beliefs, at least in part, in the new experiential psychologies fashioned out of Locke's observations in An Essay Concerning Human Understanding (1690 and especially the fourth edition in 1700). ${ }^{63}$ In so doing, they helped to forge links between notions of republican social-political order and mental philosophy, and revealed the new psychology's ultimate inability to prescribe any one reading of the nature of talents.

The two major Enlightenment experiential approaches to the mind were associationism, codified in England by David Hartley, and sensationalism, the French ver-

\footnotetext{
${ }^{61}$ On ideas about heredity in America, see Charles E. Rosenberg, "The Bitter Fruit: Heredity, Disease, and Social Thought," in No Other Gods: On Science and American Social Thought (Baltimore: Johns Hopkins Univ. Press, 1978), pp. 25-53. For France, see Carlos López-Beltrán, " 'Les Maladies héréditaires': 18th Century Disputes in France," Rev. Hist. Sci. 48 (1995): 307-50.

${ }^{62}$ Rousseau and Paine are two examples of eighteenth-century writers who relied on a faculty understanding of the human mind.

${ }^{63}$ John Locke, An Essay Concerning Human Understanding, 2 vols. (New York: Dover, 1959).
} 
sion of Lockeanism articulated by Etienne-Bonnot de Condillac. Both were characterized by a commitment above all to the constitutive power of experience. ${ }^{64}$ In brief, associationism and sensationalism each sought to ground human knowledge and abilities on sensations and the associations of ideas produced by sensations. Subsuming and exceeding Locke's rejection of innate ideas in favor of the tabula rasa, Hartley and Condillac stressed the passivity of the mind in all of its operations. Experience alone, both contended, furnished the mind with all of its raw materials and with most of the powers by which those materials could be manipulated. Condillac's famous example of the statue, presented in his Traité des sensations (1752), illustrated the nature of these Enlightenment theories of the mind well. Condillac asked his readers to imagine a statue internally constructed like a human being and with a mind totally devoid of ideas. He then sequentially endowed it with each of the five senses and showed how, on the basis solely of the experiences acquired via sense perceptions and their associations, all human faculties, ideas, and abilities would arise:

The principle determining the development of its [the statue's] faculties is simple. It is comprehended in the sensations themselves, for these being naturally pleasant or unpleasant, the interest of the statue will be to enjoy the one kind and reject the other. Now we are able to show that this interest is sufficient to explain the operations of the understanding and the will. Judgment, reflexion, desires, passions, \&c. are only sensations differently transformed. ${ }^{65}$

While there were numerous internal inconsistencies in both the sensationalist and associationist versions of experiential psychology, the basic message was clear. As Condillac mused in the final sentences of the Traité: "The statue is therefore nothing but the sum of all it has acquired. May not this be the same with man?"66

For proponents of an education-based explanation of the origins of an individual's talents, associationism and sensationalism were easily rendered into forms that would provide strong support. Godwin, for example, referred throughout his Enquiry Concerning Political Justice to the general principles of associationist psychology and, at length, to Hartley's theories. He used them to buttress his claim "that the actions and dispositions of mankind are the offspring of circumstances and events, and not of any original determination that they bring into the world." 67 Physiologically oriented authors, while they had a more difficult time of it, also proved adept at grounding their accounts of talents as gifts of nature on the precepts of experiential psychology. In general, their approach was to concede that all ideas must be based on experience but to contend that different mental physiologies would result in the same set of experiences being processed in distinct ways and thus would result in the expression of different individual talents or the same talent to varying

\footnotetext{
${ }^{64}$ David Hartley, Observations on Man. His Frame, His Duty, and His Expectations (London: Leake, Frederick, Hitch, and Austin, 1749); Etienne-Bonnot de Condillac, "Essai sur l'origine des connoissances humaines" (1746), reprinted in Oeuvres complètes de Condillac (Paris: Houel, 1798); and idem, Condillac's Treatise on Sensations (1754), trans. Geraldine Carr (London: Favil Press, 1930).

${ }^{65}$ Condillac, Treatise on Sensations (cit. n. 64), pp. xxxi-xxxii.

66 Ibid., p. 239.

${ }^{67}$ Godwin, Enquiry (cit. n. 42), vol. 1, p. 26.
} 
degrees. Diderot for one used arguments of this kind in developing his critiques of radically environmentalist interpretations of human mental characteristics. ${ }^{68}$ And Pierre-Jean-Georges Cabanis explored them even more fully in a series of lectures he gave before the National Institute beginning in 1796, published in book form in 1802 as Rapports du physique et du moral de l'homme. ${ }^{69}$

Like so many other eighteenth-century writers investigating the operations of the mind, Cabanis began with Locke. "It was Locke who for the first time clearly exposed and fortified with his most direct proofs, this fundamental axiom: THAT ALL IDEAS COME THROUGH THE SENSES, or ARE THE PRODUCT OF THE SENSATIONS." ${ }^{70}$ Cabanis departed from Locke, and from his successors Condillac and Hartley as well, however, by following Diderot's route and tying sensationalist psychology to human physiology. Human physiology, Cabanis contended, taught that human beings naturally vary, that "the different organs or systems of organs do not have the same degree of force or effect in different subjects. Each person has his strong and his weak organs." ${ }^{11}$ Much of Rapports, in fact, was given over to illustrating how variations - whether caused by heredity, disease, age, climate, diet, or occupation-in the various organs, especially the genitalia, produced the great differences that existed among individuals and between at least certain kinds of human groups (such as men and women, or young and old).

According to Cabanis and most other advocates of a physiological understanding of talents, the environmentalists' theory that differences arose because each individual had his or her own unique set of experiences was insufficient. Even were two individuals to have exactly the same sensations over their entire lives, Cabanis contended, they would still exhibit distinct mental characteristics because their internal structures, especially their brains, not being exactly the same, would process the sensations differently. "Men are certainly not alike in the way in which they feel," Cabanis noted, "age, sex, temperament, illness, set up notable differences between them, and in the same man the various impressions have, according to their nature and many other incidental circumstances, a very unequal degree of force or of acuteness." 72

These two divergent ways of reading Enlightenment experiential psychology-as supporting either an environmentalist or physiological interpretation of the origin of human mental characteristics-illustrate both the newfound proximity of the language of mental philosophy to the language of social-political theory and the ambiguities that surrounded Enlightenment deployments of the word "talents." The ambiguities were heightened because either reading of the new psychology could be used to support a variety of theories about republican governance. For figures such as Godwin, committed to the radical restructuring of human society along egalitar-

\footnotetext{
${ }^{68}$ Denis Diderot, "Refutation of the Work of Helvétius Entitled On Man" (1773-1776), reprinted in Diderot's Selected Writings, ed. Lester G. Crocker and trans. Derek Coltman (New York: Macmillan, 1966), pp. 283-98; and idem, "Réflexions sur le livre De l'esprit par M. Helvétius" (1758), reprinted in Oeuvres complètes, vol. 9: L'Interpretation de la nature (1753-1765), Idées III, ed. Jean Varloot (Paris: Hermann, 1981), pp. 261-312.

${ }^{69}$ Pierre-Jean-Georges Cabanis, On the Relations between the Physical and Moral Aspects of Man, 2 vols. (1802), ed. George Mora and trans. Margaret Duggan Saidi (Baltimore: Johns Hopkins Univ. Press, 1981).

${ }^{70}$ Ibid., vol. 1, p. 10.

${ }^{71}$ Ibid., vol. 1 , p. 60 .

${ }^{72}$ Ibid., vol. 1, pp. 51-2.
} 
ian lines, the potential benefits of notions of mind as enormously malleable were obvious: every putative difference between individuals or groups that could be used to justify a particular social hierarchy was vitiated if all differences were deemed the result of education. ${ }^{73}$ Almost as readily, however, the same theory about the nature of the human mind could be used to support a position such as that of Adam Smith, who also contended that differences in talent were largely the product of education, but nonetheless concluded that a highly differentiated, and stratified, workforce was essential to a nation's prosperity and a society's happiness. ${ }^{74}$

Similarly, while arguments in favor of hierarchy and the status quo could be sustained relatively easily by reference to human mental characteristics as the products of native endowment, neither Paine nor Diderot, for example, had any difficulty in reconciling such a position on the origins of the faculties with their own interest in the radical transformation of society. Convinced that talents, while gifts of nature, were spread equally throughout all social classes and that republics required a diversity of talents to prosper, the two men concluded that a republican society must make opportunity equally available to all. ${ }^{75}$ What was less possible for those who adopted a physiological orientation, however, was to conceive of a society in which hierarchy of every sort was deemed artificial and thus eliminable. For them, the reality of talents typically made distinctions of some kind seem both inevitable and justified. Moreover, because the meaning of "talent" typically carried with it some sense of comparative superiority, and the kinds of talents that they deemed relevant to articulations of the nature of republican societies were highly circumscribed, the slippage between superiority in one domain and superiority overall easily occurred, as Jefferson's conception of the natural aristocracy vividly demonstrates. ${ }^{76}$

The range of possible ways in which conceptions of merit, understandings of talents, and theories of society and governance could be rendered and combined by republican theorists in the late eighteenth century was thus quite large. Even among the group of liberal and radical writers who attracted Adams's particular ire, substantial disagreements existed over just how perfectible (to use Adams's language) human beings were, as well as over issues of the heritability of talents, their nature and number, and their relative importance in placing limits on the kind of republican state and society that seemed feasible. ${ }^{77}$ In order to explore these connections in more depth, we will conclude with an examination of three authors-Helvétius, Paine, and Wollstonecraft-who were routinely grouped by critics as part of the same radical Enlightenment attack on the foundations of traditional society, and who can be seen, nonetheless, to have adopted very different positions on the source of human talents and their role in defining the nature of a republican polity.

\footnotetext{
${ }^{73}$ As Godwin argued, "A principle deeply interwoven with both monarchy and aristocracy in their most flourishing state, but most deeply the latter, is that of hereditary pre-eminence. No principle can present a deeper insult upon reason and justice. Examine the new-born son of a peer, and of a mechanic. Has nature designated in different lineaments their future fortune?" Godwin, Enquiry (cit. n. 42 ), vol. 2 , p. 86 .

${ }^{74}$ Smith, Wealth of Nations (cit. n. 13), vol. 1, bk. 1, chap. 2, especially pp. 16-7.

${ }^{75}$ See Paine, Rights of Man (cit. n. 29), p. 175.

${ }^{76}$ Thus even Paine did not advocate the elimination of all social distinctions, but simply their placement on a more rational footing.

${ }^{77}$ On eighteenth-century ideas about perfectibility, see Victor Hilts, "Enlightenment Views on the Genetic Perfectibility of Man," in Transformation and Tradition in the Sciences: Essays in Honor of I. Bernard Cohen, ed. Everett Mendelsohn (Cambridge: Cambridge Univ. Press, 1984), pp. 255-71.
} 


\section{HELVÉTIUS, THE EGALITARIAN CHALLENGE, AND THE ENLIGHTENMENT LEGACY}

Ironically, the Enlightenment writer who may have caused late-eighteenth-century radicals their most significant problems was one of the century's great champions of equality, Claude-Adrien Helvétius. A tax farmer turned philosopher, seen as something of a protégé of Voltaire, Helvétius became one of the most notorious radicals of the French Enlightenment, a figure almost on a par with Julien Offray de La Mettrie and Rousseau. Helvétius's two major philosophical works, De l'esprit (1758) and De l'homme (1772-1773), constituted the most thoroughgoing eighteenthcentury arguments in favor of the natural equality of human beings and came to be seen as representative of some of the most extreme possibilities of Enlightenment thought, influencing - if only negatively-almost all those writing about such topics after him. ${ }^{78}$ Extremely well known, at least by reputation, throughout the republic of letters and beyond, both works generated an enormous amount of controversy, including criticism from almost every point on the political and intellectual spectrum.

There was little, on the surface, about Helvétius's theory of mind that would have seemed particularly novel to a student of Condillac or Locke. Bypassing all of the equivocations and hesitancies apparent in Condillac's formulation, Helvétius accepted without reservation Condillac's insistence on the primacy of experience, made experience the cardinal principle of his philosophy, and boldly, and perhaps bluntly, deduced the consequences. Experience alone, Helvétius maintained in both De l'esprit and De l'homme, determined every facet of the unimpaired human mind. ${ }^{79}$ Innate ideas, innate faculties - both were banished from Helvétius's theory in favor of a mind composed solely of sensations and the associations of sensations. For Helvétius, a person was the sum of his or her experiences, no more and no less. Where Helvétius deviated from Condillac, besides in the lack of nuance, was in what he deduced from this emphasis on experience and in how he attempted to convince his readers of the truth of his deductions. Simply put, Helvétius concluded that if human minds were the result of nothing but sensations and their associations, then intrinsically all minds must be the same and all differences, even those between geniuses and ordinary people, must arise solely from variations in experience. "Genius is not the gift of nature," Helvétius remarked, “. . . a man of genius spends his time in study and application." 80

Thus, according to Helvétius, any person could become a genius. But if that were so, Helvétius wondered, why in fact was genius so rare? The final sentence of $D e$ l'esprit suggested his answer, an answer that Helvétius would develop more fully in De l'homme - politics:

[I]t is certain that the great men that are now produced by a fortuitous concourse of circumstances, will become the work of the legislature, and that, by leaving it less in

\footnotetext{
${ }^{78}$ Claude Adrien Helvétius, De l'esprit; or Essays on the Mind and Its Several Faculties (1758) (New York: Burt Franklin, 1970); and idem, A Treatise on Man: His Intellectual Faculties and His Education (1772-1773), trans. William Hooper, 2 vols. (London: Albion Press, 1810).

${ }^{79}$ For an excellent discussion of Helvétius's philosophy and how it changed between De l'esprit and De l'homme, see C. Kiernan, "Helvétius and a Science of Ethics," Stud. Voltaire 18th Cent. 60 (1968): 229-43.

${ }^{80}$ Helvétius, Essays on the Mind (cit. n. 78), p. 359.
} 
the power of chance, an excellent education may infinitely multiply the abilities and virtues of the citizens in great empires. ${ }^{81}$

In De l'homme, Helvétius would show himself to be much less sanguine about empires and much more enamored of republics as the way to ensure the general education of the public. ${ }^{82}$ Nonetheless, what is critical here is not which political system Helvétius found most appropriate, but that the conclusion to an essay on the mind would be a call for civic reform. Helvétius was certainly not the only Enlightenment writer to merge philosophy and politics, but his linking of the potential equality of human minds with their actual inequality made the issue of social change particularly acute. For if all human beings were endowed with the same potential for experiencing and associating sensations, and experience produced all differences, including the whole range of current inequalities, then changing experience along the appropriate lines, especially through the state's establishment of a comprehensive system of education, should be sufficient to increase the mental abilities of the populace. All that was necessary, Helvétius contended, was both the desire to expand the mental abilities of the citizenry and the willingness to have the state be an active agent of social change.

Helvétius actually devoted little attention in either of his treatises to the practicalities of achieving such an improvement in the capabilities of the citizenry. He was also rather reticent on the issue of how some individuals were able to manifest genius at all, despite the impediments and ridicule generated by contemporary society. Nevertheless, rather than being dismissed as idle philosophical speculation, Helvétius's books, especially De l'esprit, generated an extraordinary amount of public controversy. As David W. Smith has noted in his excellent study of the reaction to the publication of De l'esprit:

No book during the whole of the eighteenth century, except perhaps Rousseau's Emile, evoked such an outcry from the religious and civil authorities or such universal public interest. Denigrated as the epitome of all the dangerous philosophic trends of the age, condemned as atheistic, materialistic, sacrilegious, immoral, and subversive, it [De l'esprit] enjoyed an immense succès de scandale. ${ }^{83}$

While Helvétius's pronouncements about human equality added some fuel to the fire, in the main the scandale erupted because of his theory of human morality and his willingness, as Smith argues, to seem to resurrect the dreaded materialism of $\mathrm{La}$ Mettrie's L'Homme machine (1748). Like La Mettrie, Helvétius was read as doing away with the human soul and free will by advocating a strictly mechanical determinism driven by sensation and a sensibility potentially present in all matter. ${ }^{84}$ Nonetheless, the dramatic events that surrounded the publication of De l'esprit-its appearance in late July and the annulment on 10 August of the privilège that allowed it to be published in France; its condemnation, along with the Encyclopédie and other exemplars of Enlightenment philosophe thought, by most Parisian religious and civil bodies; and its author's three retractions (two before the Jesuits and one

\footnotetext{
${ }^{81}$ Ibid., p. 498.

${ }^{82}$ See particularly Kiernan, "Helvétius and a Science of Ethics" (cit. n. 79).

${ }^{83}$ David W. Smith, Helvétius: A Study in Persecution (Oxford: Clarendon Press, 1965), p. 1.

${ }^{84}$ Ibid., p. 13.
} 
before the Parlement as he tried to forestall further censure)—conspired to make its arguments widely known and much discussed. ${ }^{85}$

Broad dissemination, however, did not produce many converts. For all of the egalitarianism of much of the rhetoric of the late eighteenth century, few people were willing to go as far as Helvétius in their commitment to the full natural equality of human beings. Adams, writing to Jefferson in 1813, summed up in his typical nononsense manner the reaction to Helvétius common in much of the transatlantic world:

I have never read Reasoning more absurd, Sophistry more gross, in proof of the Athanasian Creed, or Transubstantiation, than the subtle labours of Helvetius and Rousseau to demonstrate the natural Equality of Mankind. Jus cuique [Justice for everyone]; the golden rule; do as you would be done by; is all the Equality that can be supported or defended by reason, or reconciled to common Sense. ${ }^{86}$

Adams did not get Rousseau quite right, for Rousseau was only slightly more sympathetic to Helvétius than was Adams. ${ }^{87}$ But Adams did capture the incredulity with which many contemporary and subsequent writers and political thinkers reacted to Helvétius's theories ${ }^{88}$ The visceral quality of the response to Helvétius is most illuminating. Helvétius struck a nerve, and that nerve may have had much to do with the nature of the republics that these political thinkers were so assiduously attempting to invent.

The problem was simple: What space existed for merit in Helvétius's theory? If Helvétius were right, and each human being was completely a product of education, then, as he pointed out, it ought to be possible for the state, by educating all equally, to produce the same level of talents and virtues in every citizen. Fine in theory, but in practice, what would it have meant for a social and political order to be structured around merit if there were no legitimate criteria of differentiation? If human beings were nothing but unmolded clay and society had the power to shape all to become the best conceivable, then how could anyone justify the existence of social distinctions? Either an absolutely egalitarian society would have to be established-a prospect with few proponents on either side of the Atlantic-or recourse would have to be made to arbitrary distinctions, a solution difficult to square with condemnations of hereditary aristocracy on the very same grounds. Helvétius threatened to bring the whole edifice of merit tumbling down and fashioned his arguments on the basis of a theory of the human mind conceded to have many strong arguments in its favor. While some theorists did unite experiential psychology with notions of physiological difference, these claims were at best highly disputed in the late eighteenth century. The safest approach to Helvétius, and the one most often taken, was to dismiss his ideas as chimerical, and then to move on to less troubling matters. Adams followed this solution in his letter to Jefferson, and Voltaire, Helvétius's one-time patron, did so even more pointedly in a letter to Prince Golitsin in 1773: "No one will convince me that all minds are equally suitable to science, and that they differ only

\footnotetext{
${ }^{85}$ For the details of the story of the response to De l'esprit, I have relied on the excellent account provided by Smith in Helvétius (cit. n. 83), especially pp. 1-3 and passim.

${ }^{86}$ Adams to Jefferson, 13 July 1813, Adams-Jefferson Letters (cit. n. 1), p. 355.

${ }^{87}$ See Jean-Jacques Rousseau, Emile, or Education (1762), trans. Eleanor Worthington (Boston: Ginn, Heath, \& Co., 1883).

${ }^{88}$ On reactions to De l'esprit among philosophes, see Smith, Helvétius (cit. n. 83), pp. 157-71.
} 
in regard to education. Nothing is more false: nothing is demonstrated more false by experience." ${ }^{89}$ After the tumultuous events of the American and French revolutions, few authors of the time would have disagreed with Voltaire. Even radical republicans such as Paine and Wollstonecraft formulated their approaches to remaking the social order on decidedly different grounds.

\section{TALENTS SOWN TO THE WIND: PAINE'S RIGHTS OF MAN AND THE ASSAULT ON ARISTOCRACY}

Partisan of the American and French revolutions, one of the most noted political pamphleteers of his day, and a supporter of radical causes of all stripes, Thomas Paine carried out a tireless campaign near the end of the century against the power and, indeed, the very existence of hereditary aristocracy. Nonetheless, Paine did not follow Helvétius's lead and reject the concept of an elite entirely. Rather, committed to the idea that power and sovereignty resided in the people (however this entity was to be understood), Paine represented monarchic governments and social systems founded on hierarchies of birth as violating the ultimate principle of Enlightenment thought, rationality, and of doing so through a failure to take adequate account of one of the natural facts about human beings - the distribution of talents throughout the population. As Paine argued in his jeremiad against hereditary aristocracy, The Rights of Man (1791-1792):

We have heard the Rights of Man called a levelling system; but the only system to which the word levelling is truly applicable is the hereditary monarchical system. It is a system of mental levelling. It indiscriminately admits every species of character to the same authority. Vice and virtue, ignorance and wisdom, in short, every quality, good or bad, is put on the same level. Kings succeed each other, not as rationals, but as animals. It signifies not what their mental or moral characters are. ${ }^{90}$

There was perhaps no greater calumny that Paine could have cast on hereditary monarchy than to suggest that the system was more associated with the practices of unreasoning brutes than with the methods of civilized and rational human beings. By so doing, he accentuated the strategic role that he accorded mental and moral characteristics in his argument because those attributes traditionally marked the dividing line between the human and animal worlds. Human mental attributes were valuable tools for Paine in the attack on aristocracy because, grounded in nature, they carried the highest legitimacy possible in the eighteenth century, and, independent of birth, they "proved" that hereditary systems of social organization were inadequate to the needs of state and society. In the process, Paine-and many other opponents of hereditary aristocracy as well - constructed a vision of government in which an individual's mental characteristics replaced birth and blood as the rhetorical criteria by which distributions of power and the restructuring of society could rationally be justified. ${ }^{91}$

\footnotetext{
${ }^{89}$ François Marie Arouet de Voltaire to Prince Dmitry Alekseevich Golitsin, 19 June 1773, The Complete Works of Voltaire, vol. 124: Correspondence (Oxfordshire: Voltaire Foundation, 1975), vol. 40, p. 29.

${ }^{90}$ Paine, Rights of Man (cit. n. 29), p. 172.

${ }^{91}$ As Alexander Hamilton observed in Federalist No. 68: "It will not be too strong to say that there will be a constant probability of seeing the station [the presidency] filled by characters pre-eminent for ability and virtue." Hamilton, Madison, and Jay, Federalist Papers (cit. n. 39), p. 414. See also Paine, Rights of Man (cit. n. 29), pp. 163-4.
} 
To accomplish his goals of delegitimizing hereditary aristocracy on the basis of its violation of the principles of reason and of developing a new model for the structure of society, Paine imported into his analysis certain "truths" about two aspects of the natural history of human talents. First, he argued vociferously and repeatedly that mental and moral abilities did not follow any simple law of heredity and thus that there was no warrant for the belief that a good king in one generation would be likely to produce a talented monarch in the next:

Could it be made a decree in nature, or an edict registered in heaven, and man could know it, that virtue and wisdom should invariably appertain to hereditary succession, the objections to it would be removed; but when we see that nature acts as if she disowned and sported with the hereditary system; that the mental characters of successors, in all countries, are below the average of human understanding; that one is a tyrant, another an idiot, a third insane, and some all three together, it is impossible to attach confidence to it, when reason in man has power to act. ${ }^{92}$

Second, Paine insisted that not only were the talents necessary to good government and a republican society many and varied, but from generation to generation they were scattered throughout all social classes, so that only a society that remained open to developing abilities wherever they lay could be deemed to be operating in concert with the dictates of reason and nature. "It appears to general observation, that revolutions create genius and talents; but those events do no more than bring them forward," Paine asserted. ". . . [T] he construction of government ought to be such as to bring forward, by a quiet and regular operation, all the extent of capacity which never fails to appear in revolutions." 93

In essence, Paine combined his argument against aristocracy with an argument in favor of a form of social-political order in which he cast merit as the basis for justifying distributions of power and represented merit itself as tightly bound to particular understandings of the nature and distribution of individual talents. Paine painted the open, liberal, and nonaristocratic society that he envisioned as the logical response to a set of what he took to be natural facts about human beings: that human minds were replete with faculties, that the power of these faculties was largely a consequence of physiology, that powers of mind were rarely inherited, and that talents and abilities were distributed widely and unpredictably throughout the whole of a population. Human nature, properly understood, provided the vehicle by which he could dispense with hereditary monarchy and in its place erect a republican order open to all on the basis of merit, without losing entirely the sense that hierarchy and difference would persist.

\section{"THE RANK THAT REASON ASSIGNED HER": WOLLSTONECRAFT AND THE VINDICATION OF WOMEN}

Although closely allied with Paine and fully supportive of his attack on hereditary monarchy, Mary Wollstonecraft had a somewhat different view of the origin of talents and their distribution among the various social groups. ${ }^{94}$ In developing her case

\footnotetext{
${ }^{92}$ Paine, Rights of Man (cit. n. 29), p. 173

${ }^{93}$ Ibid., p. 176.

${ }^{94}$ On Wollstonecraft's background, see Miriam Brody, introduction to A Vindication of the Rights of Woman (cit. n. 14), pp. 4-20; and Virginia Sapiro, A Vindication of Political Virtue: The Political Theory of Mary Wollstonecraft (Chicago: Univ. of Chicago Press, 1992), chap. 1.
} 
for the extension to women of the claims of republican citizenship and the full rights of participation within civil society-articulated most forcefully in A Vindication of the Rights of Woman-Wollstonecraft argued from a kind of middle position, employing faculty psychology and an understanding of talents that conceived of them as shaped by both nature and education.

Wollstonecraft opened Vindication by conceding that most women, in their current degraded state, were generally frivolous, coquettish, and cunning, exhibiting few of the intellectual abilities or virtues required of active citizens in a republic. ${ }^{95}$ She maintained, however, that this state of affairs had come to pass largely because women had been trained to act in such a manner; with educations similar to those of men, she argued, women would exhibit virtues and talents at least similar in kind:

I will allow that bodily strength seems to give man a natural superiority over woman; and this is the only solid basis on which the superiority of the sex can be built. But I still insist that not only the virtue but the knowledge of the two sexes should be the same in nature, if not in degree, and that women, considered not only as moral but rational creatures, ought to endeavour to acquire human virtues (or perfections) by the same means as men, instead of being educated like a fanciful kind of half being-one of Rousseau's wild chimeras. ${ }^{96}$

Women had this potential, Wollstonecraft contended, because all members of the human race were, by definition, endowed with the same types of mental faculties. The question of difference was solely one of degree and could be determined only by providing women and men with an identical education. Once women were able to exercise their mental faculties to the fullest, she argued, then and only then would it be possible to determine the types of political rights and social roles appropriate for them. Wollstonecraft even accepted the possibility, at least rhetorically, that women might prove the inferior of men in those characteristics of greatest importance to a republican society. She maintained only that women deserved the right to find out: "Further, should experience prove that they [women] cannot attain the same degree of strength of mind, perseverance, and fortitude, . . . woman would then only have the rank that reason assigned her, and arts could not be practised to bring the balance even, much less to turn it."97

Both here and throughout Vindication, Wollstonecraft accepted without reservation the position that at least certain rights and opportunities should be consequent on the degree of an individual's or group's virtues and talents. ${ }^{98}$ In addition to illustrating the extent to which civic and political rights had become linked with assessments of mental capacity, however, her exploration of the potentials of the language of merit for justifying a role for women in civil society reveals much about the

\footnotetext{
${ }^{95}$ One of Wollstonecraft's first rhetorical moves was to represent military officers as "idle superficial young men" because of the nature of their educations, and then to assert that women and officers were in completely similar states. See Wollstonecraft, Vindication, pp. 97, 104-8, also chap. 4. Brody remarks on this feature of Wollstonecraft's argument in introduction to Vindication (both cit. n. 14), pp. 44-5.

${ }_{96}$ Wollstonecraft, Vindication (cit. n. 14), p. 124.

${ }^{97}$ Ibid., p. 121.

${ }^{98}$ As Wollstonecraft asserted early in her discourse: "That the society is formed in the wisest manner, whose constitution is founded on the nature of man, strikes, in the abstract, every thinking being so forcibly, that it looks like presumption to endeavour to bring forward proof.' Ibid., p. 92.
} 
ways in which the discourse of merit could be employed to construct differences and distinctions. Whether in absolute terms (exemplified by their use in the exclusion of women from political power) or in relative terms - illustrated by Wollstonecraft's willingness to concede the justice of a social hierarchy established on rational principles - "natural" differences among groups and individuals became freighted with political meaning, and the distinction between nature and nurture began to take on powerful significance. For the core of Wollstonecraft's argument was that women, and any other group or indeed any individual, deserved just that rank in society consonant with the mental capacities with which they had been endowed.

Vindication, in fact, leaves little doubt that Wollstonecraft believed women to be equal to men in terms of native intellectual abilities. Indeed, she reminded her readers of the existence of prominent women whose skills were so manifest as to require no further justification of their possession of faculties the equal of any male. ${ }^{99} \mathrm{But}$ by couching her argument in terms of native endowments and faculties able to differ in their power by degree, she left open the possibility that new truths about the actual potentials of various types of human intellects could have significant political and social repercussions. If women's mental faculties were indeed proven to be physiologically inferior, for example, then there would be strong grounds, according to the logic of Wollstonecraft's argument, to limit women's role in political and civil life. The basis for this possibility of exclusion lay in her willingness, at least rhetorically, to make the facts about human nature, whatever they might be determined to be, stand as the final arbiter. Given her own middle position on the relative roles of nature and education in producing talents, she left open to question how far education could remedy inequities in the distribution of talents and thus how egalitarian a republican society could be.

\section{CONCLUSION}

The responses of Paine and Wollstonecraft to Helvétius's "provocation" illustrate the enormous number of subterranean fault lines that radiated around the concept of "talents" and its place in the Enlightenment vision of a republican society. The ambiguities surrounding "talents" gave the term enormous power and resonance. It could be used simultaneously to legitimate the persistence of social and occupational distinctions and to validate the establishment of broad-based educational systems designed to discover or foster talent across the very lines of those distinctions. It provided both a language in which to argue for greater political and social power and a means to exclude whole groups of people from all but the most basic rights. It helped hold together a system that seemed to offer opportunity to all and yet justified restricting those opportunities to only some. In other ways, however, the ambiguities surrounding "talents" presented real problems. By leaving the concept ill defined, the line determining where universal rights ended and the privileges of talent began was open to continual renegotiation. And by according mental characteristics such a prominent place in the imagined republic, the possibility was left open that changes in theories about the mind could have significant, and largely uncontrollable, effects on how the social-political order was understood and structured. As long as the system of governance remained justified in terms of claims about human nature and the

${ }^{99}$ See, e.g., ibid., pp. 119, 172. 
illuminations of reason, it was almost necessarily linked to the knowledge systems in which such entities were given definition and meaning.

In this, Jefferson and Adams can be seen to have been looking forward as well as back. Their vision of an aristocracy of intellect, while certainly risible in America of the early twenty-first century, nonetheless captured an element in republican culture that would continue to attract the energies of political thinkers and the interest of human scientists, not to mention the passions of reformers of all stripes. Jefferson and Adams identified, if nothing else, a language through which outsiders could claim inclusion and experts positions of power and authority within a democratic system of governance. What is more, their sense that human differences were of legitimate social relevance solely to the degree they were derived from nature (because nature alone could be seen to stand outside of the partisan conflict of personal interests) meant that those theorists able to claim persuasively the ability to interpret nature would conceivably be in positions to have significant social impact. By the early twentieth century, as is well known, one such group was the army of mental testers who fanned out across the United States, offering to reorganize the social order on the basis of a rationalized distribution of a number of social goodsranging from educational opportunities to employment possibilities-legitimated through their presumed ability to objectively assess what they argued was the most fundamental human talent, intelligence. That their claims to be able to measure merit in this way were, and continue to be, taken seriously is one small indication that the world imagined by Jefferson and Adams at the end of their lives did not completely disappear and that the desire to counterbalance a commitment to equality with a conception of merit rooted as much in science as in politics persisted. Once woven into the core of republican political theory, the science of human nature would prove difficult to remove. 
http://www.jstor.org

\title{
LINKED CITATIONS
}

\author{
- Page 1 of 2 -
}

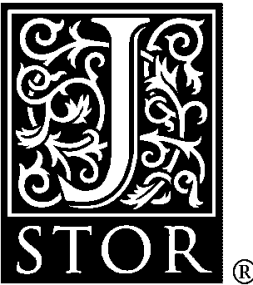

You have printed the following article:

\author{
Differentiating a Republican Citizenry: Talents, Human Science, and Enlightenment \\ Theories of Governance \\ John Carson \\ Osiris, 2nd Series, Vol. 17, Science and Civil Society. (2002), pp. 74-103. \\ Stable URL: \\ http://links.jstor.org/sici?sici=0369-7827\%282002\%292\%3A17\%3C74\%3ADARCTH\%3E2.0.CO\%3B2-Z
}

This article references the following linked citations. If you are trying to access articles from an off-campus location, you may be required to first logon via your library web site to access JSTOR. Please visit your library's website or contact a librarian to learn about options for remote access to JSTOR.

\section{[Footnotes]}

\footnotetext{
${ }^{8}$ The Army in the French Enlightenment: Reform, Reaction and Revolution

David D. Bien

Past and Present, No. 85. (Nov., 1979), pp. 68-98.

Stable URL:

http://links.jstor.org/sici?sici=0031-2746\%28197911\%290\%3A85\%3C68\%3ATAITFE\%3E2.0.CO\%3B2-S
}

\footnotetext{
${ }^{17}$ From Homme Machine to Homme Sensible: Changing Eighteenth-Century Models of Man's Image

Sergio Moravia

Journal of the History of Ideas, Vol. 39, No. 1. (Jan. - Mar., 1978), pp. 45-60.

Stable URL:

http://links.jstor.org/sici?sici=0022-5037\%28197801\%2F03\%2939\%3A1\%3C45\%3AFHMTHS\%3E2.0.CO\%3B2-5

${ }^{21}$ Benjamin Rush, David Hartley, and the Revolutionary Uses of Psychology

Donald J. D'Elia

Proceedings of the American Philosophical Society, Vol. 114, No. 2. (Apr. 13, 1970), pp. 109-118.

Stable URL:

http://links.jstor.org/sici?sici=0003-049X\%2819700413\%29114\%3A2\%3C109\%3ABRDHAT\%3E2.0.CO\%3B2-\%23
}

NOTE: The reference numbering from the original has been maintained in this citation list. 
http://www.jstor.org

\title{
LINKED CITATIONS \\ - Page 2 of 2 -
}

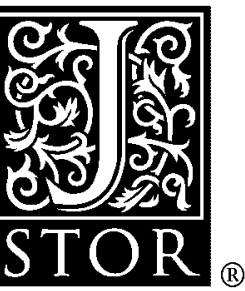

${ }^{21}$ James Madison and the Nature of Man
Ralph L. Ketcham
Journal of the History of Ideas, Vol. 19, No. 1. (Jan., 1958), pp. 62-76.

Stable URL:

http://links.jstor.org/sici?sici=0022-5037\%28195801\%2919\%3A1\%3C62\%3AJMATNO\%3E2.0.CO\%3B2-X

${ }^{26}$ Dis-Covering the Subject of the "Great Constitutional Discussion," 1786-1789

Carroll Smith-Rosenberg

The Journal of American History, Vol. 79, No. 3, Discovering America: A Special Issue. (Dec., 1992), pp. 841-873.

Stable URL:

http://links.jstor.org/sici?sici=0021-8723\%28199212\%2979\%3A3\%3C841\%3ADTSOT\%22\%3E2.0.CO\%3B2-O

\section{${ }^{32}$ The Gendered Meanings of Virtue in Revolutionary America}

Ruth H. Bloch

Signs, Vol. 13, No. 1, Women and the Political Process in the United States. (Autumn, 1987), pp. 37-58.

Stable URL:

http://links.jstor.org/sici?sici=0097-9740\%28198723\%2913\%3A1\%3C37\%3ATGMOVI\%3E2.0.CO\%3B2-T

\author{
${ }^{32}$ The Virtues of Liberalism: Christianity, Republicanism, and Ethics in Early American \\ Political Discourse \\ James T. Kloppenberg \\ The Journal of American History, Vol. 74, No. 1. (Jun., 1987), pp. 9-33. \\ Stable URL: \\ http://links.jstor.org/sici?sici=0021-8723\%28198706\%2974\%3A1\%3C9\%3ATVOLCR\%3E2.0.CO\%3B2-G
}

NOTE: The reference numbering from the original has been maintained in this citation list. 